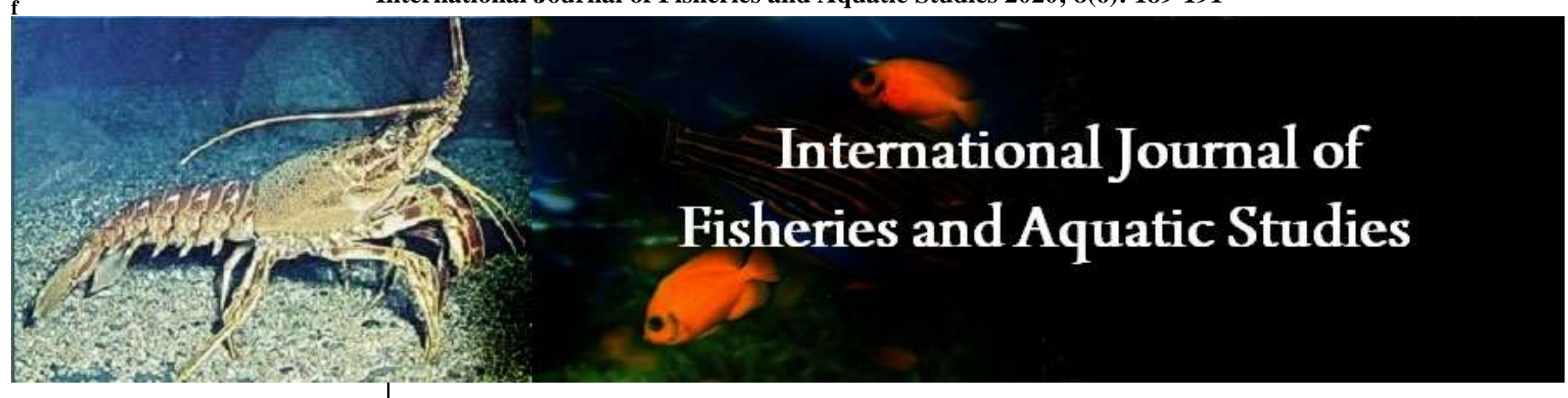

E-ISSN: 2347-5129

P-ISSN: 2394-0506

(ICV-Poland) Impact Value: 5.62

(GIF) Impact Factor: 0.549

IJFAS 2020; 8(6): 189-191

(C) 2020 IJFAS

www.fisheriesjournal.com

Received: 09-09-2020

Accepted: 18-10-2020

Sharad Deshmukh

Department of Microbiology,

S. S. Jaiswal College of Arts,

Com. and Sci. Arjuni, Morgaon,

Maharashtra, India

Gopal Paliwal

Department of Zoology,

S. S. Jaiswal College of Arts,

Com. and Sci. Arjuni, Morgaon,

Maharashtra, India

Sudhir Bhandarkar

Department of Zoology,

M. B. Patel College of Arts, Com.

and Sci. Deori, Maharashtra,

India

Sanjeev Patankar

Department of Microbiology,

S. S. Jaiswal College of Arts,

Com. and Sci. Arjuni, Morgaon,

Maharashtra, India

Manish Rajankar

Director, Bhandara Nisarga $\mathrm{v}$

Sanskruti Abhyas Mandal,

Bhandara, Maharashtra, India

Corresponding Author:

Gopal Paliwal

Department of Zoology, S. S.

Jaiswal College of Arts, Com. and

Sci. Arjuni, Morgaon,

Maharashtra, India

\section{A report of epizootic ulcerative syndrom (EUS) In Channa punctata (Bloch, 1793) from freshwater fisheries lake in Gondia district Maharashtra}

\author{
Sharad Deshmukh, Gopal Paliwal, Sudhir Bhandarkar, Sanjeev Patankar \\ and Manish Rajankar
}

DOI: https://doi.org/10.22271/fish.2020.v8.i6c.2377

\begin{abstract}
Bhandara and Gondia districts are popularly known as lakes district. Many of the water bodies being exploited for capture fisheries, contributing towards the livelihood of thousands of people; live around and depend on paddy and fish production. However occurrence of disease has become a primary problem to sustainable aquaculture production, thereby affecting the socioeconomic status of fishermen communities in the district. Different opportunistic bacterial pathogens and parasites causing a great deal of losses to the fish industry in terms of high mortality and therefore prevention of fish diseases are of paramount importance in terms of sustainable growth of aquaculture. The present investigation reveals the source of fish mortality due to the severe bacterial infestation of Aeromonas causing red spotted disease and death of fishes in the Kokna Jamidari Lake of the Kokna village.
\end{abstract}

Keywords: EUS, Channa punctata, infection, aeromonas, ulceration, fisheries, Kokna, gondia

\section{Introduction}

India is endowed with vast freshwater consisting 45,000 km of rivers, 26,334 $\mathrm{km}$ of canals, 2.36 million hectares of ponds and tanks, 2.05 million hectares of reservoirs and 5,82,86,000 hectares of wetlands (Bhakta and Bandyopadhyay, 2008; Kumar et al., 2015) ${ }^{[1,2]}$. Fisheries in India are a progressively growing sector with varied resources. There are thousands of traditional lakes in the eastern vidarbha region of Maharashtra, these are also known as exmalgujari tanks widely used for irrigation and fisheries. Fishes as the keystone species determine the abundance and distribution of ecosystem biodiversity representing indicators of ecosystem health. The freshwater bodies are depleting alarmingly due to the cultural eutrophication. Bacterial infections to the fishes are most catastrophic thing in this area, locally it is known as 'Mata' (Ulcerative Syndrome); a contagious disease mostly affected to the local fishes, spread during winter than summer; affect on any part of the body and it penetrates through the body of fish (Bhandarkar et al., 2020) ${ }^{[3]}$. The development of research on fish diseases is gaining importance in India for the successful implementation of fishery development program. The recent outbreaks of fish disease, 'Epizootic Ulcerative Syndrome' (EUS) in fishes from rivers, canals, lakes, ponds of east and north eastern states of India has seriously affected fishery activities (Jhingran and Das, 1990) ${ }^{[4]}$. Epizootic Ulcerative Syndrome (EUS) spread through south East Asia and extended widely into Indian subcontinent over past decade (Rodgers and Burke 1981) ${ }^{[5]}$. A similar type of disease characterised by dermal ulcer from the rivers of south India during 1975-76 and north during 1982-88 (Haines, 1983) ${ }^{[6]}$ and gradually spread in the fresh and brackish water fishes of different states of India. EUS is commonly known as red spot disease primary etiological agents of EUS are bacteria, viruses and fungi (Jhingran and Das, 1990) ${ }^{[4]}$. In the context of bacterial disease in fish, the present investigation on Epizootic Ulcerative Syndrom (EUS) is the first report in the Gondia district. The present paper deals with the occurrence and distribution of causative agent of EUS is discussed. 


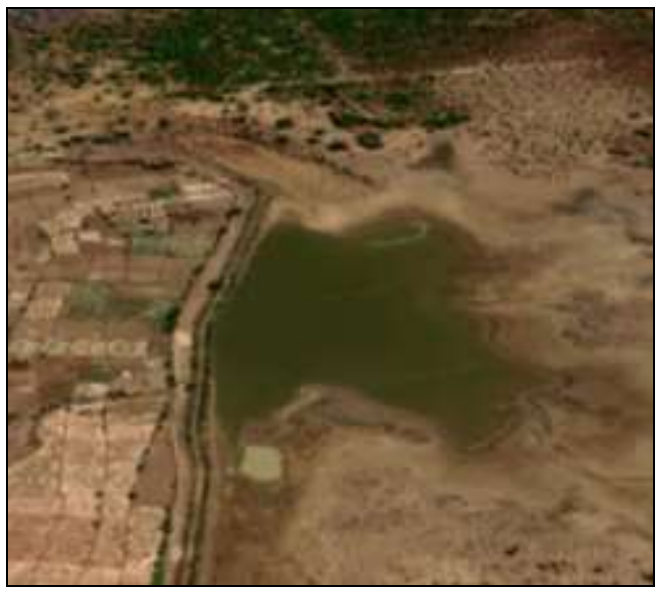

Fig 1: A Fisheries Lake of Kokna Jamidari in Gondia District

\section{Materials and Methods \\ 2.1 Sampling}

Infested fishes were collected from Kokna Jamidari Lake of the Kokna village which lies $21.0110959 \mathrm{~N}$ and $80.1247340 \mathrm{E}$ (Figure 1) in Gondia district. The fish sample collected in a sterile plastic container and brought to microbiology laboratory of our college. Lesions were observed carefully on different part of the fishes. Samples for bacteriological analysis were collected using sterile cotton swabs from ulcerative lesions of a fishes. Swabs were subjected for isolation of bacteria on Macconkey's agar and Tripticase soya agar. Isolated colonies were studied for colony character and morphology of isolates. Isolates were sent for identification to the Laboratory of Karmavir Bhaurao Patil College, Vashi, Navi Mumbai Maharashtra. The result finding was done by automated identification system.

\subsection{Specimen}

Channa Punctata (Bloch, 1793): Channa punctata also known as spotted snakehead, belongs to the family Channidae (Snakeheads) (Figure 2). Body is elongate, almost cylindrical at anterior and compressed in posterior. Head is large, dorsal and anal fin based long, pelvic fin sub-abdominal with rounded caudal fin. It burrows in mud, prefers stagnant and muddy water. It is carnivorous in habit and voracious predator of small fish and fries. Nest constructed on floating weeds. It is listed as 'Least Concerns' in IUCN Red List, but several cultural activities cause' water pollution are the potential threats.

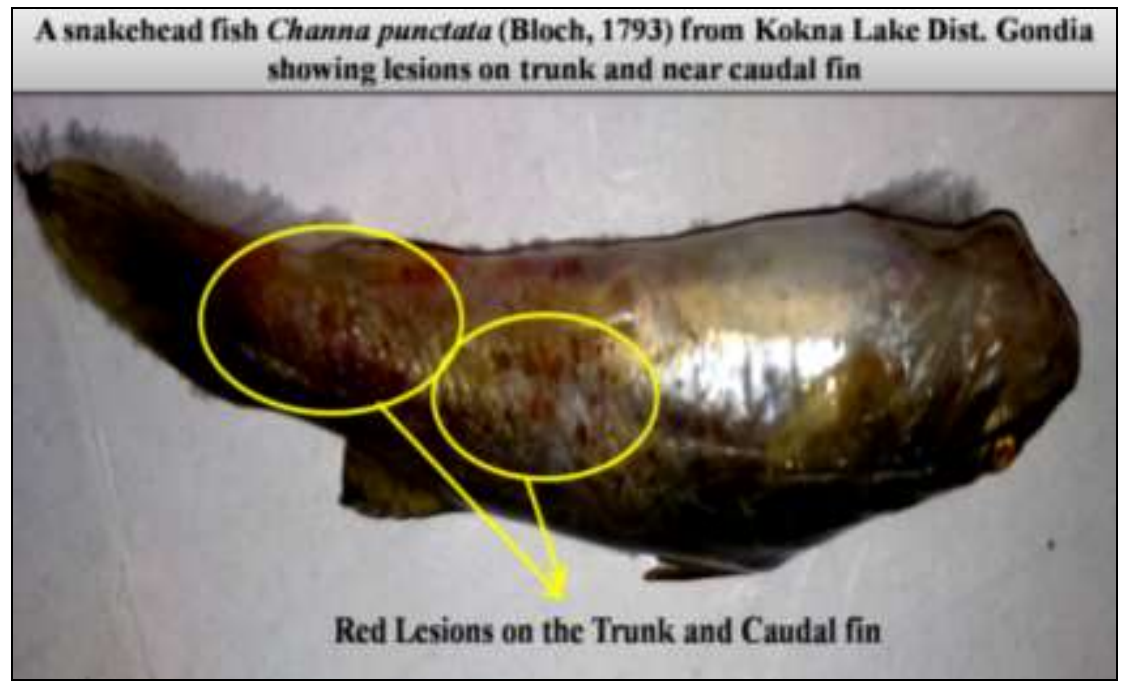

Fig 2: The Snakehead Fish Channa punctata showing Lesions on Skin

\section{Results and Discussions}

Smooth, convex, rounded, 3-4 $\mathrm{mm}$ in diameter, non-lactose fermenting colonies on Macconkey's agar were observed and subject to gram staining. Gram negative non-sporing, motile bacilli were observed. As identification was done at Karmavir Bhaurao Patil College, Vashi, Navi Mumbai Maharashtra by automated system, which were identified main cause as Aeromonas hydrophila. One of the sample isolate was identified as Serratia marcescens. Aeromonas hydrophila was isolated from the lesions on gill, trunk and caudal fin. As Serratia marcescens rarely reported from aquatic animal like fish (Baya et al., 1992) [7]. In our study also it was isolated only from one sample from the lesions of eye. Serratia marcescens from fish has also reported in the Kerla state of India (Dharmaratnam et al., 2017) ${ }^{[8]}$. Most of the common fish pathogenic species are from the genera Vibrio, Aeromonas, Flovobacterium, Yersinia, Adwardsielia, Streptococcus, Lactococcus, Renibacterium and Mycobacterium (Austin and Austin, 1999) ${ }^{[9]}$. Serratia marcescens has not been included which was isolated in the present study. In one of the study by Kozinska reported $P$. fluorescens as the most important species in fish pathology and very commonly associated with skin and fin disease (Kozinska, 1999) ${ }^{[10]}$. In Poland, Acinetobacter species found to be responsible for de-pigmentation of the skin, loss of scales, and exophthalmia with congestion of eye and gill in infected trout (Kozinska et al., 2014) ${ }^{[11]}$. Ectoparasite like sea lice Lepeophteirus salmonis can cause severe infestation were it may also transmit viral and bacterial disease i.e. Infectious Salmon Anemia (ISA) (Hastain, 2008) ${ }^{[12]}$. Overall, the above findings correlate with the Steven D Mahlen (2011) ${ }^{[13]}$ who mentioned the most important among the bacterial infections are caused by Aeromonas species particularly A. hydrophilla. This may be due to the poor defense by primary stress allowing the bacteria to enter and disrupt the skin (Sanders, 2020) [14]. Various other workers and their reports (Dharmaratnam et al., 2017; Kozinska, 1999; Kozinska et al., 2014) ${ }^{[8,10,11]}$ does not show the Aeromonas as a major cause of ulcerations. 


\section{Conclusion}

from the present study, it has been concluded that Aeromonas species are the most common cause of ulceration. This may be attributed with the poor water quality, poor nutrition, etc. such bacterial infection may hamper the welfare of affected fish unless properly treated in time.

\section{Acknowledgement}

Authors are thankful to Director of the Microbiology laboratory K.B. Patil College, Vashi, N. Mumbai, Dr. Kishor Waghmare and Dr. Manoj Bangadkar for their kind cooperation during the research.

\section{References}

1. Bhakta JN, Bandyopadhyay PK. Fish diversity in freshwater perennial water bodies in east Midnapore district of West Bengal, India. International Journal Environmental Research 2008;2(3):255-260.

2. Kumar U, Choudhary S, Kumar M, Paswan R. Physicochemical Parameters of Gamhi water body of the Kaula Chaur (Wetland) Of Begusarai District (Bihar). Proceedings of Zoological Society 2015;14(1):1-6.

3. Bhandarkar SV, Paliwal GT, Bhatia JG, Bangadkar MK. Conservation and Management of Water Bodies with Special Emphasis on Fisheries in Gondia District. Research Trend in Fisheries and Aquatic Sciences 2020;(6):1-24.

4. Jhingran AG, Das MK. Epizootic ulcerative syndrome in fishes. Central Inland Capture Fisheries Research Institute. Barrackpore. India 1990; Bulletin (65).

5. Rodgers LJ, Burke JB. Seasonal variation in the prevalence of 'red spot' disease in estuarine fish with particular reference to sea mullet. Mugil cephalus L. Journal of Fish Disease 1981;(4):297-307.

6. Haines AK. Fish Fauna and Ecology. The Purari-Tropical Environment of High Rainfall River Basin. Petr. T. (Ed.) Dr. W. Junk Publishers 1983;(51):367-384.

7. Baya AM, Toranzo AE, Luprani B, Santos Y, Hetric FM. Serratia marscencence: a potential pathogen for fish. Journal of Fish Diseases 1992;15(I):15-16.

8. Dharmaratnam A, Kumar R, Basheer VS, Sood N, Swaminathan TR, Jena JK, et al. Isolation and characterization of virulent Serratia marcencens associated with a disease outbreak in farmed ornamental fish, Poecilia reticulate in Kerala, India. Indian Journal of fisheries 2017;64(4):71-79.

9. Austin B, Austin DA. Bacterial fish pathogens: Disease in farm \& wild fish. Springer, New York, N Y, USA, $3^{\text {rd }}$ ed 1999

10. Kozinska A. Atypical cases of disorders in cyprinid wintering caused by Pseudomonas fluorescens infections. Bulletin of the European Association of Fish Pathologists 1999;(19):216-220.

11. Kozinska A, Pazdzior E, Pekala A, Niemczuk W. Acinectobacter johnsoni and Acinectobacter lowffii-the emerging fish pathogens. Bulletin of the Veterinary Institute in Pulawy 2014;(58):193-199.

12. Torud B, Hastain T. Skin lesions in fish: causes \& solutions. Acta Veterinaria Scandinavica. 2008; (50): S7.

13. 13. Mahlen SD. Serratia Infections: from Military Experiments to Current Practice. Clinical microbiology Reviews 2011;24(4):755-791.

14. Sanders J. https://www.thesprucepets.com/ulcers-infreshwater-fish-4802382. 01 November, 2020. 